\begin{abstract}
Iranica
Abstracta Iranica Revue bibliographique pour le domaine irano-aryen

Volume 32-33 | 2013

Comptes rendus des publications de 2009-2010
\end{abstract}

\title{
Dominique Hollard. Julien et Mithrā sur le relief de Tāq-e-Bostān
}

\section{Bruno Overlaet}

\section{(2) OpenEdition \\ 1 Journals}

\section{Electronic version}

URL: http://journals.openedition.org/abstractairanica/40515

DOI: 10.4000/abstractairanica.40515

ISSN: 1961-960X

\section{Publisher:}

CNRS (UMR 7528 Mondes iraniens et indiens), Éditions de l'IFRI

\section{Printed version}

Date of publication: 1 December 2013

ISSN: 0240-8910

\section{Electronic reference}

Bruno Overlaet, « Dominique Hollard. Julien et Mithrā sur le relief de Tāq-e-Bostān », Abstracta Iranica [Online], Volume 32-33 | 2013, document 171, Online since 01 July 2016, connection on 26 September 2020. URL : http://journals.openedition.org/abstractairanica/40515 ; DOI : https://doi.org/10.4000/ abstractairanica. 40515

This text was automatically generated on 26 September 2020.

Tous droits réservés 


\title{
Dominique Hollard. Julien et Mithrā sur le relief de Tāq-e-Bostān
}

\author{
Bruno Overlaet
}

\section{REFERENCES}

Dominique Hollard. " Julien et Mithrā sur le relief de Tāq-e-Bostān », in : R. Gyselen, ed., Sources for the History of Sasanian and Post-Sasanian Iran. Bures-sur-Yvette, 2010, p. 147-163. (Res Orientalis XIX)

1 The author examines the reasons for the presence of Julianus Apostata and Mithra together on the investiture relief of Ardashir II at Taq-i Bustan. Roman literary and numismatic sources serve to illustrate Julianus Apostata's syncretic religious background, his relation to the Mithraic cult and the significance of the celestial bull on his coins. Although this combination of Sol-Helios-Mithra differs, as the author shows, in many ways from the Persian Mithra, it is suggested that the Persian nobility considered Julianus' use of it as an offensive attempt to establish divine rights to the Persian realm, even more so since Hormisdas, a brother of Shapur II who took part in the Roman invasion, was to be placed on the Persian throne. Mithra is depicted to back Julianus' invalid claims to divine support, an idea first suggested by O. Nicholson ("Taqi Bostan, Mithras and Julian the Apostate: an irony", Iranica Antiqua XVIII, 1983:177-178). To account for the presence of a Roman emperor who was defeated in 363 on the relief of Ardashir who came to power in 379, Hollard likens the fallen emperor to Ahriman, while comparing the relief with the investiture of Ardashir I at Naqsh-i Rustam. He proposes seeing the investing figure as Ohrmazd. Because the latter stands on the fallen Julianus Apostata, the scene would symbolize the defeat of evil. Contrary to the statement on p. 157 however, Ardashir II also stands on the Roman emperor. P. Calmeyer explained this in terms of the role of Ardashir II in the defeat of Julianus Apostata. His paper has bearing on the present discussion ("Vom Reisehut zur Kaiserkrone: B. Stand der archäologischen Forschung zu den iranischen Kronen", Archaeologische Mitteilungen aus Iran, Neue Folge 10, 1977, p. 187-188; see, too, 
A. Shahbazi, "Studies in Sasanian Prosopography - II. The Relief of Ardašer II at Taq-i Bustān", Archaeologische Mitteilungen aus Iran, Neue Folge 18, 1985, p. 181-185, Taf. 51).

\section{AUTHORS}

\section{BRUNO OVERLAET}

Royal Museums of Art and History, Bruxelles 